\title{
SEPARATE FORM/GENRE THESAURUS TO BE ESTABLISHED
}

The Policy and Standards Division (PSD) of the Library of Congress announced plans on June 17, 2010 to formally separate form/genre terms from the Library of Congress Subject Headings (LCSH) list. The title of the thesaurus will be the Library of Congress Genre/Form Terms for Library and Archival Materials (LCGFT), and it will be published later this summer in the Supplemental Vocabularies volume of the 32nd edition of LCSH. In MARC21 bibliographic records, the genre/form terms will appear in the 655 field with a second indicator of "7" and the source code "lcgft" will be placed in subfield $\$ 2$ (e.g., $655-7$ a [Term]. \$2 lcgft). In MARC21 Authority records, the $008 / 11$ will be coded " $z$ " (Other), and the 040 \$f field will be coded "lcgft". LCCN's for the genre/form terms will contain the prefix "gf'. The timeline for implementation will be late 2010 or early 2011. Further details can be found on the PSD Web site (http://www.loc.gov/catdir/cpso/genreformthesaurus.html)

\section{OCLC WEBINAR: KAREN SMITH-YOSHIMURA ON TRANSITIONING FROM AND BEYOND MARC}

OCLC has posted links to the webinar (63.6 MB/ 1:28 min.) and slides (4.2 MB/42pp.) of Karen Smith-Yoshimura's presentation to the 2010 RLG Annual Partnership meeting held in Chicago June 10, 2010) at http://www.oclc.org/research/events/20100610marc.pptx. The webinar can be viewed by visiting http://www5.oclc.org/downloads/research/webinars/20100610marc.m4v. She reviews the findings of working groups that analyzed MARC tag usage and its import for metadata practices.

\section{ONLINE AUDIOVISUAL CATALOGERS (OLAC) CONFERENCE}

If you catalog audiovisual materials and have a yearning to go to Georgia, you may be interested in attending the next OLAC conference, which will be October 14-17, 2010 in Macon, Georgia. Online registration is available now. Details are on their Web site (http://www.olacinc.org/drupal/conference/2010/index.html).

\section{LYRASIS EDUCATIONAL OPPORTUNITIES}

The following online courses are being offered soon. For a complete list of Summer 2010 courses offered by LYRASIS, see their PDF schedule at http://www.lyrasis.org/ /media/Files/Lyrasis/Classes $\% 20$ and $\% 20$ Events/Class $\% 20$ Sched ules/LYRASIS $\% 20$ Summer $\% 20$ Class $\% 20$ Schedule $\% 202010$.ashx.

LibraryThing for Libraries and You (10 AM-noon, August 17)

Basic MARC Tagging for Serials (10 AM-noon, August 17-18)

Koha Advanced Functions (10AM-noon, August 18)

Evergreen Cataloging Module (2-4 PM, August 18-19) 